\title{
BODY SIZE AND TROPHIC POSITION IN A DIVERSE TROPICAL FOOD WEB
}

\author{
Craig A. Layman,,${ }^{1,5}$ Kirk O. Winemiller, ${ }^{2}$ D. Albrey Arrington, ${ }^{3}$ And David B. Jepsen ${ }^{4}$ \\ ${ }^{1}$ Department of Ecology and Evolutionary Biology, Yale University, P.O. Box 208106, \\ New Haven, Connecticut 06520-8106 USA \\ ${ }^{2}$ Section of Ecology and Evolutionary Biology, Department of Wildlife and Fisheries Sciences, Texas A \& M University, \\ 210 Nagle Hall, College Station, Texas 77843-2258 USA \\ ${ }_{3}^{3}$ Perry Institute for Marine Science, 100 North U.S. Highway 1, Suite 202, Jupiter, Florida 33477-5112 USA \\ ${ }^{4}$ Oregon Department of Fish and Wildlife, Corvallis Research Lab, 28655 Highway 34, Corvallis, Oregon 97333 USA
}

Abstract. We use stomach contents and stable isotope ratios of predatory fishes, collected over a 10-year time span from a species-rich river in Venezuela, to examine potential body-size-trophic-position relationships. Mean body size of predator taxa and their prey (determined by stomach content analyses) were significantly correlated, but trophic position of predators (estimated by stable isotope ratios) was not correlated with body size. This reflects no apparent relationship between body size and trophic position among prey taxa. Primary consumer taxa (algivores and detritivores) in this system are characterized by diverse size and morphology, and thus predatory fish of all body sizes and feeding strategies are able to exploit taxa feeding low in the food web. Regardless of relative body size, predators exploit short, productive food chains. For any given food chain within a complex web where predators are larger than their prey, trophic position and body size are necessarily correlated. But in diverse food webs characterized by a broad range of primary consumer body size, apparently there is no relationship between trophic position and body size across all taxa in the web.

Key words: detritivore; diet analyses; diversity; fish; food-chain length; morphology; Neotropics; predation; prey vulnerability; river; stable isotope ratios; trophic level.

\section{INTRODUCTION}

It has long been acknowledged that body size is central to the structure and function of food webs (Elton 1927), as body size is a fundamental determinant of energy flow, species diversity, and population densities (Pimm 1982, Peters 1983, Hairston and Hairston 1993, Elser et al. 1996). Size-based descriptions of trophic structure have been used increasingly over the last 20 years to provide generalizations regarding food web properties (Warren and Lawton 1987, Cohen et al. 1993, 2003, Memmott et al. 2000, Williams and Martinez 2000, Kerr and Dickie 2001, Leaper and Huxham 2002). Body size analyses may be especially useful in species-rich, reticulate, food webs in which there may be thousands of individual feeding links and complex trophic pathways (Winemiller 1990, Polis and Strong 1996). Some of the most threatened ecosystems on the planet (e.g., rain forests, coral reefs, freshwater lotic systems) are characterized by extremely complex food

Manuscript received 13 July 2004; revised 1 December 2004; accepted 31 January 2005. Corresponding Editor: B. J. Danielson.

${ }^{5}$ E-mail: cal1634@yahoo.com webs, and body size analyses may provide insights necessary to assess community- and ecosystem-level responses to human-driven perturbations.

Predators are typically larger than their prey (but for exceptions see Leaper and Huxham 2002), and thus trophic position (i.e., the average level, relative to primary producers, at which an organism feeds) often increases with body size within a given food web (Cohen et al. 1993, France et al. 1998, Jennings et al. 2001, Woodward and Hildrew 2002, Jennings and Mackinson 2003). The size-structured nature of food webs may allow specific predictions regarding ecological responses to perturbations. For example, in marine systems, commercial fisheries drive an overall reduction in food chain length because the large individuals (i.e., those targeted in most fisheries) are positioned high in the food web (Rice and Gislason 1996, Pauly et al. 1998). Examining the body-size-trophic-position relationship in other systems should reveal whether a positive correlation between the variables is an intrinsic property of food webs that transcends different underlying web structures (e.g., ecosystems dominated by simple linear food chains vs. those with reticulate food webs). 
In the present study, we examined the relationship between trophic position and body size for fish in the species-rich Cinaruco River (Venezuela). Specifically we asked: (1) Are predator and prey body size related?, and (2) Does trophic position increase with increasing predator body size? Results are evaluated with respect to specific characteristics of the complex food web, and extended to assess how the food web may be affected by commercial net fishing in the river.

\section{Methods}

The Cinaruco River is a tributary of the Orinoco River that drains the llanos (savanna) of southern Venezuela $\left(6^{\circ} 32^{\prime} \mathrm{N}, 67^{\circ} 24^{\prime} \mathrm{W}\right)$. The Cinaruco is an oligotrophic, moderate-blackwater, floodplain river with high levels of dissolved organic carbon and low $\mathrm{pH}$. Hydrology is strongly seasonal, with water levels fluctuating more than $5 \mathrm{~m}$ annually (Arrington and Winemiller 2003). Maximum width of the main channel during the dry season is $50-200 \mathrm{~m}$. The river supports a diverse fish community ( $>280$ species), with taxa representing a wide range of ecological attributes and life history strategies (Jepsen 1997, Winemiller et al. 1997, Arrington and Winemiller 2003, Hoeinghaus et al. 2003, Layman and Winemiller 2004, Layman et al. 2005).

From 1993 to 2003, predatory fishes were collected with gill nets, cast nets, and by hook and line using artificial lures, and data from all years are pooled for these analyses. Pooling data across years enabled us to examine general trends that transcend potential annual variations in predator-prey dynamics, thereby providing a general model of food web structure in the system. Importantly, the Cinaruco River has a highly predictable annual hydrology, with distinct wet and dry seasons, in which ecological interactions are set (Arrington and Winemiller 2003, Layman and Winemiller 2004). General trends in predator-prey dynamics are consistent across years, despite interannual variation in the food web (due to extent of flooding during the wet season, varying levels of fauna recruitment, etc.). For example, Jepsen et al. (1997) reported that the detritivore Semaprochilodis kneri made up almost $50 \%$ of the diet of the abundant piscivore Cichla temensis during the falling water season, but was absent from diets in the peak dry season (April). Stomach content analyses in subsequent falling water periods (1999, 2001, 2003, 2004) have revealed strikingly consistent results with S. kneri making up $\sim 50 \%$ of Cichla diets; additional stomach content analyses in the peak dry season (April of 2001, 2002, 2003, and 2004) have not revealed a single $S$. kneri in piscivore stomachs (C. A. Layman, unpublished manuscript). Data reported here are based on large sample sizes, taken throughout the annual hydrological cycle, from all river habitats; no taxa analyzed for stable isotope ratios or stomach contents were collected only in a given season or habitat. Thus, emergent food web patterns should be robust in relation to overall temporal and spatial variation within the web.

Contents from Cichla spp. and Pseudoplatystoma fasciatum stomachs were removed by pressing down the posterior region of the tongue and applying pressure on the fish's stomach while holding the fish in a headdown position (Layman and Winemiller 2004). All other species were euthanized, and stomachs removed for examination. Stomach contents were quantified volumetrically in the field using graduated cylinders. Most of the identifiable prey items were fishes (Table 1), so we restrict size-based analysis of prey to fish taxa. Often prey items were partially digested and could only be identified to genus, particularly among closely related and morphologically similar taxa. Thus, fishes identified in stomach content analyses were lumped at the generic level, and only those identified to genus were included in prey trophic position estimates. Body mass and length produce similar predator-prey sizebased patterns (Jennings et al. 2001, Cohen et al. 2003), and we present size data based on the latter. All predator and prey individuals were measured (standard length [SL] $\pm 1.0 \mathrm{~mm})$ in the field.

Collection, preservation, and preparation of tissues for stable isotope analyses follow Arrington and Winemiller (2002), and estimation of trophic position follows Layman et al. (2005). Primary consumers provide the best baseline for estimation of trophic position using $\delta^{15} \mathrm{~N}$ values, because they integrate temporal and spatial variation in isotopic signatures of basal resources (Post 2002). We identified two fish species, Semaprochilodus kneri (Characiformes: Prochilodontidae) and Metynnis hypsauchen (Characiformes: Characidae) that integrate the dominant source pools of primary production in the system: (1) S. kneri for autochthonous algal/detrital resources, and (2) M. hypsauchen for allochthonous $\mathrm{C}_{3}$ plant material. We used a standard twosource mixing model (Post 2002) to estimate trophic position of predators using these baseline taxa. Following the meta-analysis of Vanderklift and Ponsard (2003) we employ a mean $\delta^{15} \mathrm{~N}$ enrichment of $2.54 \%$ o to estimate trophic position. This is a lower enrichment value than suggested by Post (2002), and thus our estimates of predator trophic position should represent upper estimates. Samples were not available for some rare taxa, and these taxa are not included in trophic position analyses (see Table 1).

\section{RESULTS}

We analyzed 5439 stomachs of 31 predator species representing eight fish families (Table 1). Mean predator size ranged from $69.2 \pm 5.9$ to $458.2 \pm 89.7 \mathrm{~mm}$ 
TABLE 1. Species for which stomach content analyses were conducted.

\begin{tabular}{|c|c|c|c|c|c|}
\hline Species & $\mathrm{SL}(\mathrm{mm})$ & $N$ & Fish $(\%)$ & $\begin{array}{l}\text { Measurable } \\
\text { prey }\end{array}$ & $\begin{array}{c}\text { Isotope } \\
\text { analyses }\end{array}$ \\
\hline Pseudoplaystoma fasciatum & $458.2 \pm 89.7$ & 77 & 98.1 & $\mathrm{X}$ & $X$ \\
\hline Platynematichthys notatus & $428.2 \pm 74.5$ & 30 & 100 & $\mathrm{X}$ & \\
\hline Raphiodon vulpinnis & $397.5 \pm 21.2$ & 11 & 40 & & $\mathrm{X}$ \\
\hline Pseudoplaystoma tigrinum & $382.7 \pm 100.0$ & 3 & 100 & & \\
\hline Boulengerella cuvieri & $361.5 \pm 59.1$ & 292 & 100 & $\mathrm{X}$ & $\mathrm{X}$ \\
\hline Pellona castellnaeana & $356.6 \pm 86.5$ & 52 & 61.9 & $\mathrm{X}$ & $\mathrm{X}$ \\
\hline Cichla temensis & $356.3 \pm 87.1$ & 1365 & 100 & $\mathrm{X}$ & $\mathrm{X}$ \\
\hline Boulengerella lucius & $343.1 \pm 50.5$ & 411 & 100 & $\mathrm{X}$ & $\mathrm{X}$ \\
\hline Ageniosis brevifilis & $340.5 \pm 97.9$ & 4 & 33.3 & & $\mathrm{X}$ \\
\hline Cichla intermedia & $333.6 \pm 50.9$ & 307 & 97.6 & $\mathrm{X}$ & $\mathrm{X}$ \\
\hline Leiarius marmoratus & $312.2 \pm 46.8$ & 5 & 100 & & \\
\hline Plagioscion squamossissimus & $310.2 \pm 53.1$ & 115 & 94.7 & $\mathrm{X}$ & $\mathrm{X}$ \\
\hline Hydrolycus armatus & $304.9 \pm 64.3$ & 510 & 100 & $X$ & $X$ \\
\hline Hoplias malabaricus & $302.0 \pm 56.9$ & 39 & 100 & $\mathrm{X}$ & $\mathrm{X}$ \\
\hline Cichla orinocensis & $301.5 \pm 49.7$ & 755 & 99.8 & $\mathrm{X}$ & $X$ \\
\hline Brycon sp. A & $297.5 \pm 116.7$ & 4 & 16.7 & $X$ & $X$ \\
\hline Boulengerella maculata & $283.7 \pm 36.0$ & 22 & 100 & $\mathrm{X}$ & $\mathrm{X}$ \\
\hline Serrasalmus manueli & $236.8 \pm 65.2$ & 597 & 93.1 & & $\mathrm{X}$ \\
\hline Crenicichla af. lugubris & $228.6 \pm 31.8$ & 24 & 90.5 & & $\mathrm{X}$ \\
\hline Serrasalmus rhombeus & $217.5 \pm 37.6$ & 67 & 91.8 & & $X$ \\
\hline Brycon falcatus & $210 \pm 34.5$ & 11 & 80 & & $\mathrm{X}$ \\
\hline Pygocentris caribe & $193.1 \pm 36.4$ & 17 & 91.6 & & \\
\hline Cynodon gibbus & $191.2 \pm 34.7$ & 44 & 50 & & \\
\hline Acestrorhynchus falcirostris & $189.2 \pm 73.2$ & 12 & 100 & $\mathrm{X}$ & \\
\hline Agoniates anchovia & $170.0 \pm 17.7$ & 14 & 100 & $\mathrm{X}$ & $\mathrm{X}$ \\
\hline Serrasalmus medinai & $161.7 \pm 33.6$ & 16 & 38.3 & & \\
\hline Serrasalmus altuvei & $161.0 \pm 35.4$ & 29 & 84.6 & & \\
\hline Pristobrycon striolatus & $145.9 \pm 26.6$ & 58 & 61.6 & & $X$ \\
\hline Acestrorhynchus microlepis & $107.9 \pm 19$ & 464 & 96.9 & $\mathrm{X}$ & $X$ \\
\hline Acestrorhynchus grandoculis & $90.0 \pm 8.9$ & 19 & 100 & $\mathrm{X}$ & $\mathrm{X}$ \\
\hline Acestrorhynchus minimus & $69.2 \pm 5.9$ & 65 & 100 & $\mathrm{X}$ & \\
\hline
\end{tabular}

Notes: Data in the SL column are mean standard lengths ( \pm SD) of individuals for which stomach contents were analyzed, $N$ represents the total number of stomachs examined, and Fish $(\%)$ is the volumetric percentage of stomach contents identifiable as fish remains. An X in the measurable prey column indicates species for which we recovered more than one measurable prey individual in stomach content analyses (depicted in Fig. 2A), and an $\mathrm{X}$ in the isotope analyses column indicates piscivore species for which stable isotope analyses were conducted (depicted in Fig. 2B).

(mean $\pm \mathrm{SD}$ ) for individual species. Identifiable prey in stomachs included individuals from 35 genera of fish. Measurable prey individuals varied from $5 \mathrm{~mm}$ to $225 \mathrm{~mm}$. There was no correlation between mean predator size and the total volumetric proportion of stomach contents (summed across all individuals of that species) identifiable as fish remains (Table $1, F_{1,30}=0.13, P=$ $\left.0.72, R^{2}=0.005\right)$. The number of predator species in which each prey genus was identified (an estimate of prey "vulnerability," see Schoener 1989) decreased with increasing mean prey size (Fig. $1, F_{1,33}=10.5, P$ $\left.=0.003, R^{2}=0.24\right)$, based on measurable prey recovered in stomachs. Eighteen predator species had multiple identifiable and measurable fish in their stomachs and were included in size-based analyses. The mean size of prey recovered from each predatory species was significantly correlated to the mean size of the predator (Fig. 2A, $F_{1,17}=19.4, P<0.001, R^{2}=0.55$ ).
Predator trophic position, estimated using stable isotopes, was independent of predator size (Fig. 2B, $F_{1,20}$ $=0.19, P=0.68, R^{2}=0.001$, total isotope samples analyzed $=403$ ). To examine this pattern further, we used stable isotope ratios to estimate mean trophic position for each of the prey genera that were identified in piscivore stomachs. Taxa analyzed for isotopes were collected independently (i.e., individuals analyzed were not from predator stomachs), and typically were in the same size range (mean $\pm \mathrm{SD}$ ) as individuals recovered from stomachs. Mean body size and estimated trophic position were not correlated for prey genera (Fig. 2C, $F_{1,30}=0.006, P=0.94, R^{2}=0.0002$; total isotope samples analyzed $=617)$. For example, a genus of detritivorous fishes (Curimata spp., estimated trophic position $=2.08 \pm 0.38)$ had the third largest mean body size in piscivore stomachs (150 $\mathrm{mm}$ ), whereas the second smallest prey genera (Apis- 
FIG. 1. Relationship between the number of predator species in which each prey taxa (genus) was identified and mean prey taxa size (standard length $[\mathrm{SL}]$ of prey recovered from predator stomachs).
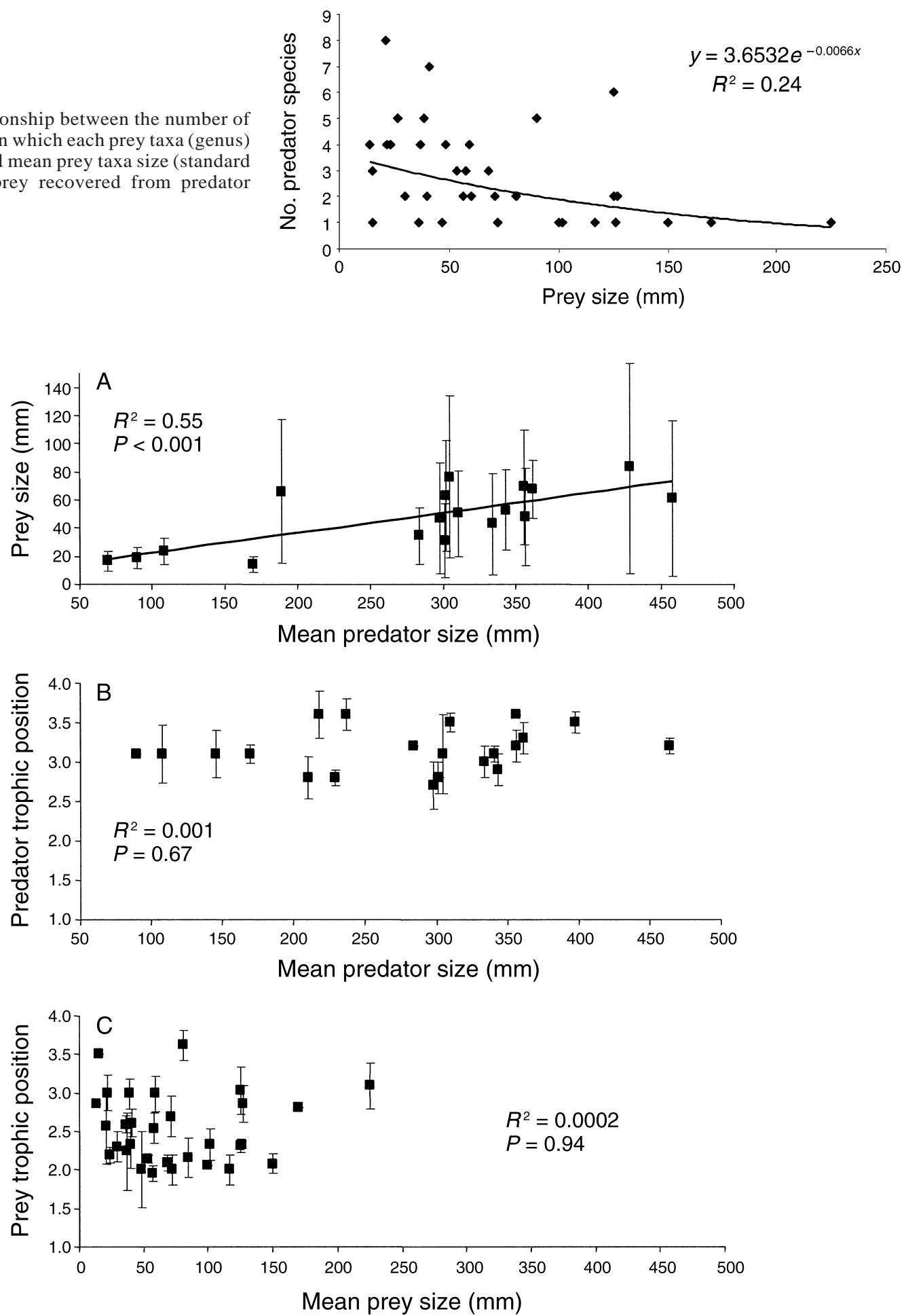

FIG. 2. Relationship between (A) mean prey and predator body size (standard length [SL]), (B) estimated mean trophic position of predators (based on stable isotope analysis) and predator body size, and (C) estimated trophic position of prey and their body size. In (A) and (B), each data point represents one predator species; in (C) each point represents one prey genus identified in stomach content analyses. In (A), mean prey and predator sizes are plotted (instead of every individual value) to enable the most direct comparison with the mean data presented in (B) and (C). Error bars represent \pm SD. 
togramma sp., $15 \mathrm{~mm}$ ) had the second highest estimated trophic position (3.5).

\section{DISCUSSION}

Although individual food chains within the Cinaruco food web were size structured, i.e., prey selection was influenced by size-based morphological constraints (Figs. 1, 2A), there was no relationship between body size and trophic position across the range of predator body sizes examined. In tropical rivers, primary consumers (i.e., herbivores and algivore/detritivores) typically are diverse in terms of size, morphology, and habitat affinity. In the Cinaruco River, primary consumer fishes exhibit a range of body sizes from some of the smallest (e.g., loricariid catfishes, adults of various species $<1 \mathrm{~g}$ ) to among the largest (Semaprochilodus laticeps, adults $>5 \mathrm{~kg}$ ) fish species in the river, a range of five orders of magnitude. This diversity is a function of far greater niche diversification in tropical than temperate freshwater fishes (Goulding 1980, Lowe-McConnell 1987, Winemiller 1990, 1991, Flecker 1992). For example, many niches exploited by insects in temperate lentic waters are filled by fishes in the tropics. Larger scope for growth in fishes (relative to insects) allows for utilization of a broad range of primary resources (e.g., nuts/seeds and different components of benthic flora), and the greater motility of fishes allows for exploitation of resources over large spatial scales (Winemiller 1990, Flecker 1992).

Piscivore species exploit prey individuals throughout the range in primary consumer body size in the Cinaruco River (Jepsen et al. 1997, Winemiller et al. 1997, Layman et al. 2005). Piscivores of all body sizes are thus able to maximize profitability (sensu Scharf et al. 2002) both by: (1) exploiting short, productive, food chains and (2) feeding on optimally sized prey. This appears to be a principal reason why tropical floodplain rivers support such high levels of secondary production (Lewis et al. 2001, Layman et al. 2005). Variation in primary consumer body size, morphology, habitat affinity, and behavior affords the opportunity for the suite of predators, characterized by diverse feeding strategies, to occupy low trophic positions (i.e., at or just above trophic position 3 , when 1 represents primary producers). And since primary consumers range from among the smallest to largest individuals in the community, all predators are able to exploit prey at energetically optimal sizes.

Our analyses provide an example of how complex food webs may obscure patterns apparent in simple food chains. In linear food chains with a single basal resource and a single predator for each prey, predators are necessarily larger than their prey (excluding parasites and other exceptional cases such as pack hunters, see Leaper and Huxham 2002). In more complex webs, each individual food chain from primary producers to secondary consumers is also size structured. But if there is a substantial range in prey body size, especially among primary consumer taxa, there may not be a positive relationship between body size and trophic position across all taxa in the web, as large predators may target relatively large primary consumers. The exact nature of the relationship between consumer body size and trophic position also will vary as a function of predator-prey body size ratios and minimum body size (D. M. Post, unpublished manuscript), but, in general, webs with a wide range of primary consumer body sizes, and piscivores that exploit a wide range of prey body sizes, will result in the lack of a strong relationship between body size and trophic position.

Food web structure is a primary determinant of ecosystem responses to perturbations. For example, fishery exploitation has been shown to reduce food chain length in marine fish communities, i.e., "fishing down the food web" (Pauly et al. 1998), because of the sizestructured food web in which the largest fishes are positioned at the highest trophic levels. Commercial netters in the Cinaruco target large fishes, including both piscivores and algivore-detritivores (Layman and Winemiller 2004). Removal of large piscivorous fishes will not decrease mean food chain length of the system, because smaller predators (that are not removed by netters) feed at a similar trophic position as the large species. Removal of abundant, large, algivore/detritivores (e.g., S. kneri), however, may result in a net increase in food chain length, as generalist predators shift their diets and consume taxa that occupy higher trophic positions (e.g., the small-bodied predators). Food web structure thus may be affected directly by removal of species, as well as indirectly by an overall decrease in secondary productivity as predators shift to feeding at trophic levels further removed from primary producers (Elton 1927). The relationship among body size and trophic position in complex food webs warrants further attention, especially in species-rich systems where human alterations to food web structure and ecosystem function are great and on-going.

\section{ACKNOWLEDGMENTS}

We thank the Cinaruco Fishing Club, Tour Apure, and Donald Taphorn for logistical support throughout the field component of this project. Alexis Medina, Carmen Montaña, and David Hoeinghaus provided valuable field and lab assistance. David Hoeinghaus, Daniel Reuman, and an anonymous reviewer provided helpful comments on the manuscript. This work was funded by a U.S. Environmental Protection Agency Science to Achieve Results Graduate Fellowship, William "Bill" Baab Conservation Fellowship, Texas A \& M Regents and Tom Slick Fellowships, a Fulbright Fellowship, and National Science Foundation grants DEB 0107456 and DEB 0089834 


\section{Literature Cited}

Arrington, D. A., and K. O. Winemiller. 2002. Use of preserved biological specimens for stable isotope analysis. Transactions of the American Fisheries Society 131:337342.

Arrington, D. A., and K. O. Winemiller. 2003. Diel changeover in sand-beach fish assemblages in a Neotropical floodplain river. Environmental Biology of Fishes 63:442-459.

Cohen, J. E., T. Jonsson, and S. R. Carpenter. 2003. Ecological community description using the food web, species abundance, and body size. Proceedings of the National Academy of Sciences (USA) 100:1781-1786.

Cohen, J. E., S. L. Pimm, P. Yodzis, and J. Saldaña. 1993. Body sizes of animal predators and animal prey in food webs. Journal of Animal Ecology 62:67-78.

Elser, J. J., D. R. Dobberfuhl, N. A. MacKay, and J. H. Schampel. 1996. Organism size, life history, and N:P stoichiometry. BioScience 46:674-684.

Elton, C. S. 1927. Animal ecology. Sidgewick and Jackson, London, UK.

Flecker, A. S. 1992. Fish trophic guilds and the structure of a tropical stream: weak direct vs. strong indirect effects. Ecology 73:927-940.

France, R., M. Chandler, and R. Peters. 1998. Mapping trophic continua of benthic food webs: body size-delta N15 relationships. Marine Ecology Progress Series 174:301306

Goulding, M. 1980. The fishes and the forest. University of California Press, Berkeley, California, USA.

Hairston, N. G. J., and N. G. S. Hairston. 1993. Cause-effect relationships in energy flow trophic structure and interspecific interactions. American Naturalist 142:379-411.

Hoeinghaus, D., C. A. Layman, D. A. Arrington, and K. O. Winemiller. 2003. Spatiotemporal variation in fish assemblage structure in tropical floodplain creeks. Environmental Biology of Fishes 67:379-387.

Jennings, S., and S. Mackinson. 2003. Abundance-body mass relationships in size-structured food webs. Ecology Letters 6:971-974.

Jennings, S., J. K. Pinnegar, N. V. C. Polunin, and T. W. Boon. 2001. Weak cross-species relationships between body size and trophic level belie powerful size-based trophic struc turing in fish communities. Journal of Animal Ecology 70 934-944.

Jepsen, D. B. 1997. Fish species diversity in sand bank habitats of a neotropical river. Environmental Biology of Fishes 49:449-460.

Jepsen, D. B., K. O. Winemiller, and D. C. Taphorn. 1997. Temporal patterns of resource partitioning among Cichla species in a Venezuelan blackwater river. Journal of Fish Biology 51:1085-1108.

Kerr, S. R., and L. M. Dickie. 2001. The biomass spectrum: a predator-prey theory of aquatic production. Columbia University Press, New York, New York, USA.

Layman, C. A., and K. O. Winemiller. 2004. Size-based prey response to piscivore exclusion in a Neotropical river. Ecology 85:1311-1320.

Layman, C. A., K. O. Winemiller, and D. A. Arrington. 2005. Describing the structure and function of a Neotropical river food web using stable isotope ratios, stomach contents, and functional experiments. In J. C. Moore, P. De Ruiter, and V. Wolters, editors. Dynamic food webs: multispecies as- semblages, ecosystem development, and environmental change. Elsevier/Academic Press, Burlington, Massachusetts, USA, in press.

Leaper, R., and M. Huxham. 2002. Size constraints in a real food web: predator, parasite, and prey body-size relationships. Oikos 99:443-456.

Lewis, W. M. J., S. K. Hamilton, M. A. Rodríguez, J. F. I. Saunders, and M. A. Lasi. 2001. Foodweb analysis of the Orinoco floodplain based on production estimates and stable isotope data. Journal of the North American Benthological Society 20:241-254.

Lowe-McConnell, R. H. 1987. Ecological Studies in Tropical Fish Communities. Cambridge University Press, London, UK.

Memmott, J., N. D. Martinez, and J. E. Cohen. 2000. Predators, parasitoids and pathogens: species richness, trophic generality and body sizes in a natural food web. Journal of Animal Ecology 69:1-15.

Pauly, D., V. Christensen, J. Dalsgaard, R. Froese, and F. Torres. 1998. Fishing down marine food webs. Science 279:860-863.

Peters, R. H. 1983. The ecological implications of body size. Cambridge University Press, Cambridge, UK.

Pimm, S. L. 1982. Food webs. Chapman and Hall, London, UK.

Polis, G. A., and D. R. Strong. 1996. Food web complexity and community dynamics. American Naturalist 147:813846.

Post, D. M. 2002. Using stable isotopes to estimate trophic position: models, methods, and assumptions. Ecology 83: 703-718.

Rice, J., and H. Gislason. 1996. Patterns of change in the size spectra of numbers and diversity of the North Sea fish assemblage, as reflected in surveys and models. ICES Journal of Marine Science 53:1214-1225.

Scharf, F. S., J. A. Buckel, and F. Juanes. 2002. Size-dependent vulnerability of juvenile bay anchovy Anchoa mitchilli to bluefish predation: does large body size always provide a refuge? Marine Ecology Progress Series 233:241-252.

Schoener, T. W. 1989. Food webs from the small to the large. Ecology 70:1559-1589.

Vanderklift, M. A., and S. Ponsard. 2003. Sources of isotopic variation in consumer-diet $\mathrm{d} 15 \mathrm{~N}$ enrichment: a meta-analysis. Oecologia 136:169-182.

Warren, P. H., and J. H. Lawton. 1987. Invertebrate predatorprey body size relationships: an explanation of upper triangularity in food webs and patterns in food web structure. Oecologia 74:231-235.

Williams, R. J., and N. D. Martinez. 2000. Simple rules yield complex food webs. Nature 404:180-183.

Winemiller, K. O. 1990. Spatial and temporal variation in tropical fish trophic networks. Ecological Monographs 60: 331-367.

Winemiller, K. O. 1991. Ecomorphological diversification in lowland freshwater fish assemblages from five biotic regions. Ecological Monographs 61:343-365.

Winemiller, K. O., D. C. Taphorn, and A. Barbarino-Duque 1997. Ecology of Cichla (Cichlidae) in two blackwater rivers of southern Venezuela. Copeia 1997:690-696.

Woodward, G., and A. G. Hildrew. 2002. Body-size determinants of niche overlap and intraguild predation within a complex food web. Journal of Animal Ecology 71:10631074. 